\title{
MicroRNA regulation of vascular function
}

\author{
David Mellis and Andrea Caporali \\ University/BHF Centre for Cardiovascular Science, The Queen's Medical Research Institute, University of Edinburgh, Edinburgh, UK
}

Correspondence should be addressed to A Caporali: a.caporali@ed.ac.uk

\begin{abstract}
MicroRNAs (miRNAs) are small non-coding RNAs that orchestrate genetic networks by modulating gene expression. Given their importance in vascular development, homeostasis and diseases, along with the technical feasibility in deploying their function in vivo, the so-called 'vascular miRNAs' have become key targets for therapeutic intervention. Herein, we have summarised the state-of-the-art on vascular miRNAs and we have discussed the role miRNA biogenesis and the extracellular vesicles (EVs) miRNA transport in vascular biology.
\end{abstract}

\section{Introduction to miRNAs in vascular biology}

MicroRNAs (miRNAs) are a member of the small non-coding RNA family; they are 22 nucleotides and are strong post-transcriptional regulator of gene expression. The specificity of miRNA targeting is defined by the complementarities between positions 2 and 8 of miRNA 5 '-end (also termed the seed sequence), with generally the 3 -untranslated region of target mRNAs. The capacity of miRNAs to simultaneously inhibit many different mRNAs allows for an amplification of biological responses (1). The reference repository miRBase, currently holds information about 1917 human precursors and 2656 mature miRNAs (release 22) (2). In the last decade, the importance of miRNAs in vascular biology has consolidated, with miRNAs being established one of the major posttranscriptional regulatory elements in vascular biology. Among the miRNAs deposited in miRBase, 42 have been described as associated with endothelial cell function and angiogenesis (3). The ability of miRNAs to regulate vascularisation and to target several genes simultaneously makes them an extremely attractive target for therapeutic angiogenesis.

Analysis of miRNA transcription and target recognition have been extensively studied in the past years; however, two regulatory mechanisms will deserve specific attention in the future: regulation of miRNA biogenesis and intercellular transfer.

\section{Regulation of miRNA biogenesis in vascular biology}

Most miRNAs are transcribed by RNA polymerase II as primary pri-miRNA transcripts, and undergo further processing by Drosha and Dicer nuclease complexes to produce miRNA duplexes 19-24bp in length (4).

Research in the past few years has provided novel knowledge of miRNA biogenesis which have been also described in the vascular cells (Fig. 1). To date, there are not studies that describe aspects of miRNA biogenesis that are specific only for vascular cells.

Dicer-dependent control of miRNA expression plays an important role in the regulation of vascular function. Dicer is critical for embryonic (5) and postnatal angiogenesis (6) and regulates endothelial miRNA expression (7). Endothelial Dicer promotes endothelial inflammation and atherosclerosis in part by miR-103-mediated suppression of KLF4 (8). Interestingly, ageing-induced dysregulation of Dicer1-dependent 


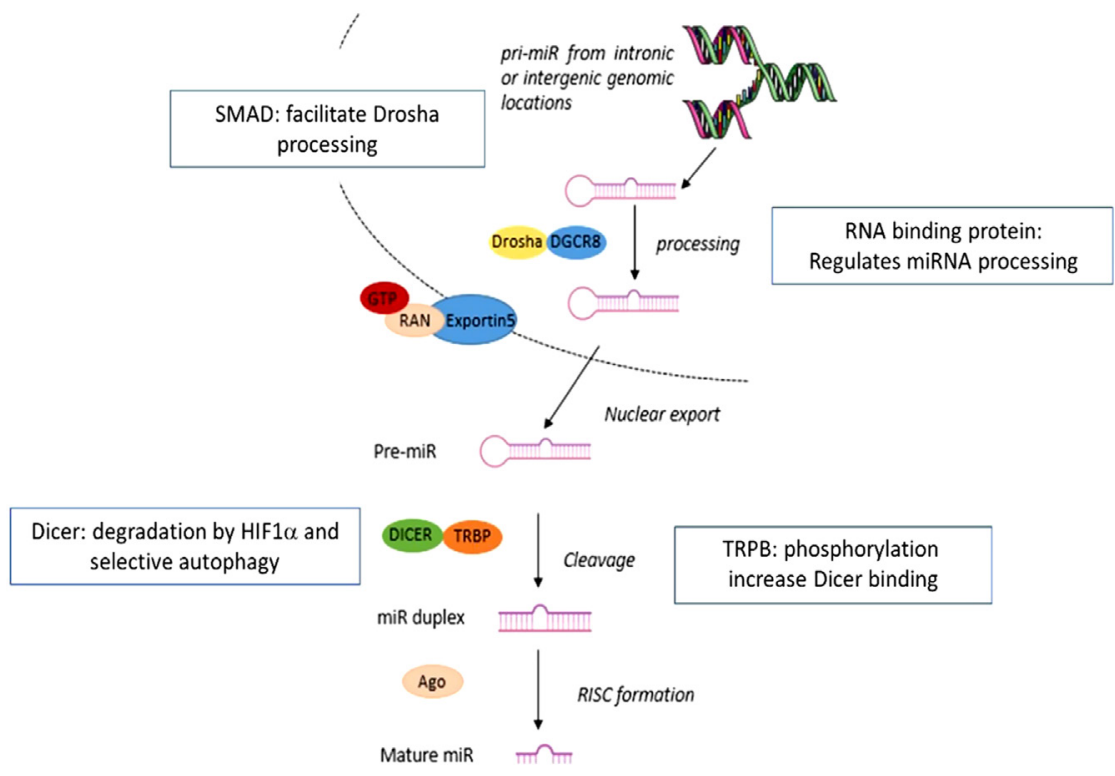

Figure 1

Regulation of miRNA biogenesis in vascular cells.
miRNA expression impairs angiogenic capacity of rat brain microvascular endothelial cells (ECs) (9).

Drosha, as well as Dicer, a key role in endothelial miRNA expression (7). Drosha-deficient zebrafish showed abnormalities in vascular development, and mice with an endothelial-specific knockout of Drosha exhibited disorganised, dilated vasculature and haemorrhage, which resemble the clinical presentations of HHT patients (10). Interestingly, the knockout of Drosha-regulating proteins DEADbox RNA helicases p68-p72 is embryonically lethal and knockout embryos display severe malformation of blood vessels (11). Argonaute 2 (AGO2)-associated miRNAs and mRNAs encoding cytoskeletal, contractile, adhesive and extracellular matrix (CAM) proteins have been identified (12). Inhibition of DROSHA or AGO2 promoted a contractile phenotype in endothelial and fibroblast cells in vitro, and increased tissue stiffness, contractility and extracellular matrix deposition in the zebrafish fin fold in vivo (12).

Crosstalk between different cellular pathways and miRNA biogenesis has been reported, and it is likely that many more such connections will be unravelled. For example, the regulatory potential of RNA-binding protein (RBPs) is tightly linked to miRNA biogenesis, and a broad layer of miRNA regulation by RBPs can be predicted (13). A recent paper demonstrated that posttranscriptional regulation of $14 \mathrm{q} 32$ miRNAs is mediated by the cold-inducible RBP (CIRBP) and hydroxyacylCoA dehydrogenase trifunctional multienzyme complex subunit beta (HADHB) during vascular regeneration after ischaemia (14). Specifically, CIRBP and HADHB are upregulated after hind-limb ischaemia in mice and regulates the processing of miR-329 (14).

Furthermore, crosstalk between miRNA biogenesis and signal transduction through phosphorylation of miRNA-processing enzymes is emerging as an important regulatory principle in vascular disease. The regulation of miR-21 is crucial in vascular biology and SMADs are recruited to pri-mir-21 in a complex with the RNA helicase p68 and facilitate its DROSHA-mediated processing (15, 16). MAPK signalling affects miRNA biogenesis. TRBP is phosphorylated by the MAPK ERK, which increases the stability of the Dicer-TRBP complex and stimulates miRNA production (17). Additional stabilisation of TRBP is achieved through its phosphorylation by ribosomal protein S6 kinase (S6K), which is activated by ERK and mTOR, thereby integrating input from different signalling pathways. This also contributes to a pro-growth miRNA expression signature in lymphatic ECs and can be pharmacologically modulated (18).

Interestingly, also autophagy has been linked with miRNA biogenesis. DICER and AGO2 are targeted for degradation by the selective autophagy receptor NDP52. Autophagy establishes a checkpoint required for continued loading of miRNA into AGO2, and it is required for activity of miRNAs (19). Notably in the context of the vascular biology, a recent study showed HIF- $1 \alpha$ binds directly Dicer and enhances its autophagy-mediated degradation by facilitating Dicer ubiquitination by the E3 ligase Parkin (20). https://vb.bioscientifica.com

https://doi.org/10.1530/VB-19-0009
(C) 2019 The authors Published by Bioscientifica Ltd

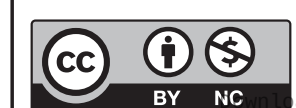

This work is licensed under a Creative Commons Attribution-NonCommercial 4.0 International License. 
miRNA intercellular transfer and signalling via EVs

A revolutionary hypothesis, that extracellular miRNA can mediate cell-cell signalling via paracrine or even endocrine routes, emerged after several research groups found that substantial amounts of miRNA purified with extracellular vesicles (EVs) including microvesicles (MVs) and exosomes $(21,22)$. MVs are a heterogeneous population of EVs up to $2 \mu \mathrm{m}$ in diameter called which are formed by budding and shedding of the cell membrane, a process that involves calcium-dependent signalling and enzyme activity. On the other hand, exosomes $(50-100 \mathrm{~nm})$ are a homogenous population of Evs, which are released from cells when multivesicular bodies (MVBs) fuse with the plasma membrane in a highly regulated process and release their contents (23).

Multiple follow-up publications demonstrated that miRNAs entrapped within various EVs can be transferred to recipient cells, alter gene expression and provoke functional effects (24). Moreover, several studies reported that miRNA content in exosomes was significantly different from that in parental cells, indicating that extracellular miRNAs may be selectively packed into the EVs (24). The extracellular miRNAs embedded in EVs are protected from nucleases activity $(22,25)$. Some studies report absence of AGO2 in the exosomes sub-group of EVs (26), whereas others report the presence of AGO2 protein (27). In this regard, RISC proteins in EVs could process precursor miRNAs (pre-miRNAs) into mature miRNAs, inducing the cell-independent miRNA biogenesis (28).

Recently a different theory on extracellular miRNAs has been proposed: the association of AGO protein-bound miRNAs with exosomes, microvesicles and apoptotic bodies could be explained by the well-known capacity of AGO2 to bind the membranes (29). It is possible that all extracellular miRNAs detected so far reside outside EVs, raising further dispute about the putative mechanisms of their export and penetration into target cells. Based on this hypothesis, the extracellular miRNAs have the potential to serve just as diagnostic tools for vascular disease with a limited transfer between the cells.

\section{Effects of intra- and extracellular miRNAs on vascular function}

Recent studies have revealed important roles for miRNAs in regulating either physiological angiogenesis or post-ischaemic neovascularisation, particularly through the regulation of EC function (Table 1). The expression of miRNA in murine models of hind-limb ischaemia has been profiled showing that miR-100 (30), miR-424 (31) and miRNAs belong to miR-106b-25 cluster (32) control perfusion recovery and angiogenesis. Interestingly, inhibition of miRNAs belonging to the $14 \mathrm{q} 32$ locus has led to improvements in post-ischaemic blood flow in vivo (33). The regulatory effects on angiogenesis are not surprising within this miRNA cluster as it is known to target critical angiogenic factors including vascular endothelial growth factor A (VEGF-A) (33). The miR17-92 cluster is upregulated in hypoxic tissues and serves a proangiogenic role. The proangiogenic function of this cluster is associated with miR-18a and miR-19a (34), whereas the anti-angiogenic function with miR-92a. Systemic administration of miR-92a inhibitor restored vascularisation in a mouse model of hind-limb ischaemia and myocardial infarction (35). Recently, our work demonstrated that miR-503 has a prominent role in diabetes-induced impairment of post-ischaemic reparative neovascularisation $(36,37)$. miR-15a, miR-16 and miR-503 belong to the same family of miRNAs with overlapping targets because of common seed sequence (38). Transplantation of healthy circulating proangiogenic cells where miR-15a and 16 were inhibited, improved post-ischaemic blood flow recovery and vascularisation (39).

To better understand what miRNAs are involved in regulating the vasculature and what contribution they have in the disease pathology, numerous methods for detecting miRNAs and tools for overexpressing and knocking down miRNAs have been designed (40). One novel approach is to identify miRNAs involved in angiogenesis is high-content screening. In our own experiment, we used human miRNA mimic library to identify miRNAs important in the proliferation of ECs, a critical stage in the process of angiogenesis. Through this technique, we identified miRNA-26b as a positive regulator of endothelial cell proliferation and survival (41).

Endothelial MVs promote re-endothelialisation following endothelial injury in mice by stimulating endothelial migration and proliferation upon transfer of functional miR-126 to target endothelium, with subsequent downregulation of SPRED1 (42). We have demonstrated that NF-kB signalling induced miR-503 transcription and the shedding of endothelial MVs by triggering the expression of Rho kinase (36). miR-503containing endothelial MVs are taken up by pericytes in vivo, thus increasing vessel permeability (36). Furthermore, miR-143 and miR-145 packaged in

This work is licensed under a Creative Commons Attribution-NonCommercial 4.0 International License. 

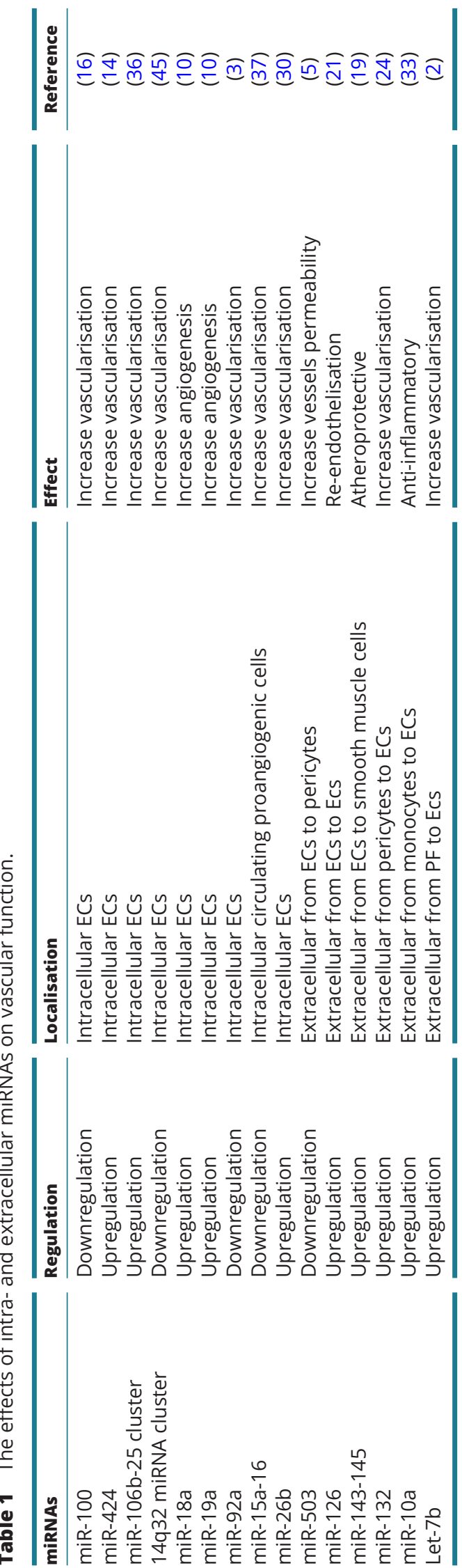

https://vb.bioscientifica.com https://doi.org/10.1530/VB-19-0009
miRNA

endothelial EVs released under shear stress are taken up by smooth muscle cells, where they downregulate target genes, inducing atheroprotective effects (43). On the other hand, pericyte-derived miR-132 is taken up by ECs, resulting in a higher proangiogenic capacity (44). A recent study showed that several anti-inflammatory microRNAs including miR-10a were transferred to monocytic cells from EC-EVs and could repress inflammatory signalling through the targeting of several components of the NF- $\mathrm{BB}$ pathway (45). Finally, analysis of pericardial fluid (PF) showed that exosomes are enriched in proangiogenic miRNAs (46). Delivery of PF exosomes in a mouse model of hind-limb ischaemia improved post-ischaemic blood flow recovery and angiogenesis in mice (46).

\section{Conclusions}

There is no disputing that miRNAs have a huge influence on angiogenesis and vascular homeostasis and have the potential to be the next generation of vascular therapeutics, however, several technical challenges remain before this can become a reality and incorporated into daily treatments for vascular disease. Analysis of miRNA biogenesis in vascular biology could reveal new mechanisms to regulate miRNA abundance. Importantly, selective pharmacologic regulation of the mechanisms involved in post-transcriptional regulation of miRNA biogenesis, such as inhibition of ERK or S6 kinases, could provide a foundation for therapeutic intervention in cardiovascular diseases underpinned by deregulated miRNA levels. Finally, the understanding of the fundamental roles of each type of EVs have in the vessels and the discovery of the comprehensive mechanism behind the sorting of miRNAs inside the EVs are the key steps to develop EVs as a tool for efficient therapeutic angiogenesis in vascular disease.

\section{Declaration of interest}

The authors declare that there is no conflict of interest that could be perceived as prejudicing the impartiality of this review.

\section{Funding}

This work did not receive any specific grant from any funding agency in the public, commercial, or not-for-profit sector.

\section{Acknowledgements}

A C and D M acknowledge the support of the British Heart Foundation (BHF). Because of space restriction, only a few recent publications were discussed in this review; we apologise to all our colleagues whose work has not been cited here. 


\section{References}

1 Bartel DP. MicroRNAs: target recognition and regulatory functions. Cell 2009136 215-233. (https://doi.org/10.1016/j.cell.2009.01.002)

2 Kozomara A, Birgaoanu M \& Griffiths-Jones S. miRBase: from microRNA sequences to function. Nucleic Acids Research 201947 D155-D162. (https://doi.org/10.1093/nar/gky1141)

3 Fernandez-Hernando C \& Suarez Y. MicroRNAs in endothelial cell homeostasis and vascular disease. Current Opinion in Hematology 2018 25 227-236. (https://doi.org/10.1097/MOH.0000000000000424)

4 Ha M \& Kim VN. Regulation of microRNA biogenesis. Nature Reviews: Molecular Cell Biology 201415 509-524. (https://doi.org/10.1038/ nrm3838)

5 Yang WJ, Yang DD, Na S, Sandusky GE, Zhang Q \& Zhao G. Dicer is required for embryonic angiogenesis during mouse development. Journal of Biological Chemistry 2005280 9330-9335. (https://doi. org/10.1074/jbc.M413394200)

6 Suarez Y, Fernandez-Hernando C, Yu J, Gerber SA, Harrison KD, Pober JS, Iruela-Arispe ML, Merkenschlager M \& Sessa WC. Dicerdependent endothelial microRNAs are necessary for postnatal angiogenesis. PNAS 2008105 14082-14087. (https://doi. org/10.1073/pnas.0804597105)

7 Kuehbacher A, Urbich C, Zeiher AM \& Dimmeler S. Role of Dicer and Drosha for endothelial microRNA expression and angiogenesis. Circulation Research 2007101 59-68. (https://doi.org/10.1161/ CIRCRESAHA.107.153916)

8 Hartmann P, Zhou Z, Natarelli L, Wei Y, Nazari-Jahantigh M, Zhu M, Grommes J, Steffens S, Weber C \& Schober A. Endothelial Dicer promotes atherosclerosis and vascular inflammation by miRNA-103mediated suppression of KLF4. Nature Communications 2016710521. (https://doi.org/10.1038/ncomms10521)

9 Ungvari Z, Tucsek Z, Sosnowska D, Toth P, Gautam T, Podlutsky A, Csiszar A, Losonczy G, Valcarcel-Ares MN, Sonntag WE, et al. Aginginduced dysregulation of dicer1-dependent microRNA expression impairs angiogenic capacity of rat cerebromicrovascular endothelial cells. Journals of Gerontology: Series A, Biological Sciences and Medical Sciences 201368 877-891. (https://doi.org/10.1093/gerona/gls242)

10 Jiang X, Wooderchak-Donahue WL, McDonald J, Ghatpande P, Baalbaki M, Sandoval M, Hart D, Clay H, Coughlin S, Lagna G, et al. Inactivating mutations in Drosha mediate vascular abnormalities similar to hereditary hemorrhagic telangiectasia. Science Signaling 201811 eaan6831. (https://doi.org/10.1126/scisignal.aan6831)

11 Fukuda T, Yamagata K, Fujiyama S, Matsumoto T, Koshida I, Yoshimura K, Mihara M, Naitou M, Endoh H, Nakamura T, et al. DEAD-box RNA helicase subunits of the Drosha complex are required for processing of rRNA and a subset of microRNAs. Nature Cell Biology 20079 604-611. (https://doi.org/10.1038/ncb1577)

12 Moro A, Driscoll TP, Boraas LC, Armero W, Kasper DM, Baeyens N, Jouy C, Mallikarjun V, Swift J, Ahn SJ, et al. MicroRNA-dependent regulation of biomechanical genes establishes tissue stiffness homeostasis. Nature Cell Biology 201921 348-358. (https://doi. org/10.1038/s41556-019-0272-y)

13 Treiber T, Treiber N, Plessmann U, Harlander S, Daiss JL, Eichner N, Lehmann G, Schall K, Urlaub H \& Meister G. A compendium of RNA-binding proteins that regulate microRNA biogenesis. Molecular Cell 201766 270.e13-284.e13.

14 Downie Ruiz Velasco A, Welten SMJ, Goossens EAC, Quax PHA, Rappsilber J, Michlewski G \& Nossent AY. Posttranscriptional regulation of $14 \mathrm{q} 32$ microRNAs by the CIRBP and HADHB during vascular regeneration after ischemia. Molecular Therapy: Nucleic Acids 201914 329-338. (https://doi.org/10.1016/j.omtn.2018.11.017)

15 Davis BN, Hilyard AC, Lagna G \& Hata A. SMAD proteins control DROSHA-mediated microRNA maturation. Nature $2008 \mathbf{4 5 4} 56-61$. (https://doi.org/10.1038/nature07086)

16 Davis BN, Hilyard AC, Nguyen PH, Lagna G \& Hata A. Smad proteins bind a conserved RNA sequence to promote microRNA maturation by Drosha. Molecular Cell 201039 373-384. (https://doi. org/10.1016/j.molcel.2010.07.011)

17 Paroo Z, Ye X, Chen S \& Liu Q. Phosphorylation of the human microRNA-generating complex mediates MAPK/Erk signaling. Cell 2009139 112-122. (https://doi.org/10.1016/j.cell.2009.06.044)

18 Warner MJ, Bridge KS, Hewitson JP, Hodgkinson MR, Heyam A, Massa BC, Haslam JC, Chatzifrangkeskou M, Evans GJ, Plevin MJ, et al. S6K2-mediated regulation of TRBP as a determinant of miRNA expression in human primary lymphatic endothelial cells. Nucleic Acids Research 201644 9942-9955. (https://doi.org/10.1093/nar/ gkw631)

19 Gibbings D, Mostowy S, Jay F, Schwab Y, Cossart P \& Voinnet O. Selective autophagy degrades DICER and AGO2 and regulates miRNA activity. Nature Cell Biology 201214 1314-1321. (https://doi org/10.1038/ncb2611)

20 Lai HH, Li JN, Wang MY, Huang HY, Croce CM, Sun HL, Lyu YJ, Kang JW, Chiu CF, Hung MC, et al. HIF-1alpha promotes autophagic proteolysis of Dicer and enhances tumor metastasis. Journal of Clinical Investigation 2018128 625-643. (https://doi.org/10.1172/ JCI89212)

21 Liu T, Zhang Q, Zhang J, Li C, Miao YR, Lei Q, Li Q \& Guo AY. EVmiRNA: a database of miRNA profiling in extracellular vesicles. Nucleic Acids Research 201947 D89-D93. (https://doi.org/10.1093/ nar/gky985)

22 Valadi H, Ekstrom K, Bossios A, Sjostrand M, Lee JJ \& Lotvall JO. Exosome-mediated transfer of mRNAs and microRNAs is a novel mechanism of genetic exchange between cells. Nature Cell Biology 20079 654-659. (https://doi.org/10.1038/ncb1596)

23 Ridger VC, Boulanger CM, Angelillo-Scherrer A, Badimon L, BlancBrude O, Bochaton-Piallat ML, Boilard E, Buzas EI, Caporali A, Dignat-George F, et al. Microvesicles in vascular homeostasis and diseases. Thrombosis and Haemostasis 2017117 1296-1316. (https:// doi.org/10.1160/TH16-12-0943)

24 Tkach M \& Thery C. Communication by extracellular vesicles: where we are and where we need to go. Cell 2016164 1226-1232. (https:// doi.org/10.1016/j.cell.2016.01.043)

25 Hunter MP, Ismail N, Zhang X, Aguda BD, Lee EJ, Yu L, Xiao T, Schafer J, Lee MT, Schmittgen TD, et al. Detection of microRNA expression in human peripheral blood microvesicles. PLOS ONE 2008 3 e3694. (https://doi.org/10.1371/journal.pone.0003694)

26 Jeppesen DK, Nawrocki A, Jensen SG, Thorsen K, Whitehead B, Howard KA, Dyrskjot L, Orntoft TF, Larsen MR \& Ostenfeld MS. Quantitative proteomics of fractionated membrane and lumen exosome proteins from isogenic metastatic and nonmetastatic bladder cancer cells reveal differential expression of EMT factors. Proteomics $2014 \mathbf{1 4}$ 699-712. (https://doi.org/10.1002/pmic.201300452)

27 Li L, Zhu D, Huang L, Zhang J, Bian Z, Chen X, Liu Y, Zhang CY \& Zen $\mathrm{K}$. Argonaute 2 complexes selectively protect the circulating microRNAs in cell-secreted microvesicles. PLoS ONE 20127 e46957. (https://doi.org/10.1371/journal.pone.0046957)

28 Melo SA, Sugimoto H, O'Connell JT, Kato N, Villanueva A, Vidal A, Qiu L, Vitkin E, Perelman LT, Melo CA, et al. Cancer exosomes perform cell-independent microRNA biogenesis and promote tumorigenesis. Cancer Cell 201426 707-721. (https://doi. org/10.1016/j.ccell.2014.09.005)

29 Cikaluk DE, Tahbaz N, Hendricks LC, DiMattia GE, Hansen D, Pilgrim D \& Hobman TC. GERp95, a membrane-associated protein that belongs to a family of proteins involved in stem cell differentiation. Molecular Biology of the Cell 199910 3357-3372. (https://doi.org/10.1091/mbc.10.10.3357)

30 Grundmann S, Hans FP, Kinniry S, Heinke J, Helbing T, Bluhm F, Sluijter JP, Hoefer I, Pasterkamp G, Bode C, et al. MicroRNA-100 regulates neovascularization by suppression of mammalian target of rapamycin in endothelial and vascular smooth muscle cells. Circulation 2011123 999-1009. (https://doi.org/10.1161/ CIRCULATIONAHA.110.000323) 
31 Ghosh G, Subramanian IV, Adhikari N, Zhang X, Joshi HP, Basi D, Chandrashekhar YS, Hall JL, Roy S, Zeng Y, et al. Hypoxia-induced microRNA-424 expression in human endothelial cells regulates HIF-alpha isoforms and promotes angiogenesis. Journal of Clinical Investigation 2010120 4141-4154. (https://doi.org/10.1172/JCI42980)

32 Semo J, Sharir R, Afek A, Avivi C, Barshack I, Maysel-Auslender S, Krelin Y, Kain D, Entin-Meer M, Keren G, et al. The 106b approximately 25 microRNA cluster is essential for neovascularization after hindlimb ischaemia in mice. European Heart Journal 201435 3212-3223. (https://doi.org/10.1093/eurheartj/eht041)

33 Welten SM, Bastiaansen AJ, de Jong RC, de Vries MR, Peters EA Boonstra MC, Sheikh SP, La Monica N, Kandimalla ER, Quax PH, et al. Inhibition of 14q32 microRNAs miR-329, miR-487b, miR-494, and miR-495 increases neovascularization and blood flow recovery after ischemia. Circulation Research 2014115 696-708. (https://doi. org/10.1161/CIRCRESAHA.114.304747)

34 Dews M, Homayouni A, Yu D, Murphy D, Sevignani C, Wentzel E, Furth EE, Lee WM, Enders GH, Mendell JT, et al. Augmentation of tumor angiogenesis by a Myc-activated microRNA cluster. Nature Genetics 200638 1060-1065. (https://doi.org/10.1038/ng1855)

35 Bonauer A, Carmona G, Iwasaki M, Mione M, Koyanagi M, Fischer A, Burchfield J, Fox H, Doebele C, Ohtani K, et al. MicroRNA-92a controls angiogenesis and functional recovery of ischemic tissues in mice. Science 2009324 1710-1713. (https://doi.org/10.1126/ science.1174381)

36 Caporali A, Meloni M, Nailor A, Mitic T, Shantikumar S, Riu F, SalaNewby GB, Rose L, Besnier M, Katare R, et al. p75(NTR)-dependent activation of NF-kappaB regulates microRNA-503 transcription and pericyte-endothelial crosstalk in diabetes after limb ischaemia. Nature Communications 20156 8024. (https://doi.org/10.1038/ncomms9024)

37 Caporali A, Meloni M, Vollenkle C, Bonci D, Sala-Newby GB, Addis R, Spinetti G, Losa S, Masson R, Baker AH, et al. Deregulation of microRNA-503 contributes to diabetes mellitus-induced impairment of endothelial function and reparative angiogenesis after limb ischemia. Circulation 2011123 282-291. (https://doi. org/10.1161/CIRCULATIONAHA.110.952325)

38 Caporali A \& Emanueli C. MicroRNA-503 and the extended microRNA-16 family in angiogenesis. Trends in Cardiovascular Medicine 201121 162-166. (https://doi.org/10.1016/j.tcm.2012.05.003)

39 Spinetti G, Fortunato O, Caporali A, Shantikumar S, Marchetti M, Meloni M, Descamps B, Floris I, Sangalli E, Vono R, et al.
MicroRNA-15a and microRNA-16 impair human circulating proangiogenic cell functions and are increased in the proangiogenic cells and serum of patients with critical limb ischemia. Circulation Research 2013112 335-346. (https://doi. org/10.1161/CIRCRESAHA.111.300418)

40 van Rooij E. The art of microRNA research. Circulation Research 2011 108 219-234. (https://doi.org/10.1161/CIRCRESAHA.110.227496)

41 Martello A, Mellis D, Meloni M, Howarth A, Ebner D, Caporali A \& Al Haj Zen A. Phenotypic miRNA screen identifies miR-26b to promote the growth and survival of endothelial cells. Molecular Therapy: Nucleic Acids 201813 29-43. (https://doi.org/10.1016/j. omtn.2018.08.006)

42 Jansen F, Yang X, Hoelscher M, Cattelan A, Schmitz T, Proebsting S, Wenzel D, Vosen S, Franklin BS, Fleischmann BK, et al. Endothelial microparticle-mediated transfer of microRNA-126 promotes vascular endothelial cell repair via SPRED1 and is abrogated in glucosedamaged endothelial microparticles. Circulation 2013128 2026-2038. (https://doi.org/10.1161/CIRCULATIONAHA.113.001720)

43 Hergenreider E, Heydt S, Treguer K, Boettger T, Horrevoets AJG, Zeiher AM, Scheffer MP, Frangakis AS, Yin X, Mayr M, et al. Atheroprotective communication between endothelial cells and smooth muscle cells through miRNAs. Nature Cell Biology 201214 249-256. (https://doi.org/10.1038/ncb2441)

44 Katare R, Riu F, Mitchell K, Gubernator M, Campagnolo P, Cui Y, Fortunato O, Avolio E, Cesselli D, Beltrami AP, et al. Transplantation of human pericyte progenitor cells improves the repair of infarcted heart through activation of an angiogenic program involving micro-RNA-132. Circulation Research 2011109 894-906. (https://doi. org/10.1161/CIRCRESAHA.111.251546)

45 Njock MS, Cheng HS, Dang LT, Nazari-Jahantigh M, Lau AC, Boudreau E, Roufaiel M, Cybulsky MI, Schober A \& Fish JE. Endothelial cells suppress monocyte activation through secretion of extracellular vesicles containing antiinflammatory microRNAs. Blood 2015125 3202-3212. (https://doi.org/10.1182/blood-201411-611046)

46 Beltrami C, Besnier M, Shantikumar S, Shearn AIU, Rajakaruna C, Laftah A, Sessa F, Spinetti G, Petretto E, Angelini GD, et al. Human pericardial fluid contains exosomes enriched with cardiovascularexpressed microRNAs and promotes therapeutic angiogenesis. Molecular Therapy 201725 679-693. (https://doi.org/10.1016/j. ymthe.2016.12.022)

Received in final form 3 June 2019

Accepted 10 June 2019

Accepted Preprint published online 10 June 2019 https://vb.bioscientifica.com

https://doi.org/10.1530/VB-19-0009 (c) 2019 The authors Published by Bioscientifica Ltd

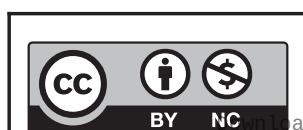

This work is licensed under a Creative Commons Attribution-NonCommercial 4 . International License. License.
ded from Bioscientifica.com at 04/26/2023 12:47:35PM 